\title{
Ultra-Performance Liquid Chromatographic Method for Measurement of Voriconazole in Human Plasma and Oral Fluid
}

\author{
Paula Boeira, ${ }^{a}$ Marina V. Antunes, ${ }^{a}$ Huander F. Andreolla, ${ }^{b}$ \\ Alessandro C. Pasqualotto ${ }^{b}$ and Rafael Linden*,a \\ aInstituto de Ciências da Saúde, Universidade Feevale, Rodovia RS 239, No. 2755, \\ 93352-000 Novo Hamburgo-RS, Brazil \\ ${ }^{b}$ Laboratório de Biologia Molecular, Santa Casa de Porto Alegre, Porto Alegre-RS, Brazil
}

\begin{abstract}
Um método simples, sensível e seletivo para determinação de voriconazol em plasma e fluido oral empregando cromatografia líquida de ultra-eficiência foi desenvolvido e validado. Após extração líquido-líquido do plasma e fluido oral com metil-tert-butil éter, o analito e o padrão interno foram separados numa coluna Hypersil Gold C18 $(2,1 \times 100$ mm, d.p. 1,9 $\mu \mathrm{m})$, eluída isocraticamente com uma mistura de tampão fosfato trietilamônio pH 3,0 e acetonitrila (70:30, v/v). O tempo total da análise foi de $4 \mathrm{~min}$, com consumo total de fase móvel de 2,2 mL. A determinação foi realizada com detector de arranjo de fotodiodos com quantificação em $256 \mathrm{~nm}$. As concentrações de voriconazol no fluido oral foram, em média, 57,5\% ( $\pm 5,3)$ daquelas determinadas em amostras pareadas de plasma.
\end{abstract}

A simple, sensitive and selective ultra-performance liquid chromatography method for the determination of voriconazole in plasma and oral fluid was developed and validated. After a liquidliquid extraction with methyl-tert-butyl ether, the analyte and internal standard were separated on a Hypersil Gold C18 column $(2.1 \times 100 \mathrm{~mm}$, p.d. $1.9 \mu \mathrm{m})$, eluted with a mobile phase composed of thietylammonium phosphate buffer and acetonitrile (70:30, v/v). Total run time was 4 min, total mobile phase consumption of $2.2 \mathrm{~mL}$. Detection was performed with a photodiode array detector with quantitation at $256 \mathrm{~nm}$. Voriconazole concentrations in oral fluid were on average $57.5 \%( \pm 5.3)$ of those measured in paired plasma samples.

Keywords: voriconazole, UPLC-PDA, oral fluid, drug monitoring

\section{Introduction}

Voriconazole (VRC), designated chemically as $(2 R$, $3 S$ )-2-(2,4-difluorophenyl)-3-(5-fluoro-4-pyrimidinyl)-1(1H-1,2,4-triazole-1-yl)-2-butanol (Figure 1), is currently the drug of choice for the treatment of invasive aspergillosis, ${ }^{1}$ based on a large trial that showed a survival benefit for patients randomized to receive VRC instead of amphotericin B deoxycholate. ${ }^{2}$ VRC is also approved for the treatment of invasive candidosis, as well as for less frequent fungal infections such as fusariosis and scedosporiosis. ${ }^{3}$ Since VRC suffers extensive hepatic biotransformation, many drugs are known to interact with this antifungal agent, which has resulted in patients presenting a wide range of VRC plasma concentrations

*e-mail: rafael.linden@feevale.br after fixed doses. Several studies have suggested that low VRC plasma concentrations may result in treatment failure, whereas high concentrations may be related to drug toxicity, especially visual disturbances, central nervous side effects and hepatotoxicity. ${ }^{4-6}$ Pascual et al. ${ }^{7}$ reported that lack of response was more frequently observed in patients with VRC levels below $1 \mu \mathrm{g} \mathrm{mL} \mathrm{mL}^{-1}$. Although there is no clear threshold for maximum acceptable VRC plasma concentrations, a cut-off of $6 \mu \mathrm{g} \mathrm{mL}{ }^{-1}$ has been recommended. ${ }^{8}$ Recently, oral fluid was suggested as alternative sample for VRC therapeutic drug monitoring (TDM), especially by its easy collection characteristics, with a relatively constant relation to plasma levels. ${ }^{9}$

Several methods are available to measure VRC concentrations in biological fluids, mainly based on high performance liquid chromatography (HPLC), with either fluorimetric, ${ }^{9}$ mass spectrometric ${ }^{10-12}$ or spectrophotometric 
detection, ${ }^{13-16}$ the former being advantageous by its robustness and lower instrumental and running costs. Moreover, VRC presents a strong absorption maximum at $256 \mathrm{~nm}$ at acidic $\mathrm{pH}$, with $\mathrm{UV}$ detection being sensitive enough to measure clinically relevant concentration in plasma. ${ }^{8}$ The specificity of the assay can be further improved with the use of a photodiode array detector (PDA), allowing spectral comparisons and peak purity evaluation, what is especially useful in the presence of other drugs. ${ }^{17}$ Moreover, spectrophotometric detection is free from matrix ionization effects observed in liquid chromatography-mass spectrometry. Besides these advantages of PDA detection, the need of complete chromatographic separation of the analytes and matrix components usually results in long analytical runs, leading to low throughput and high consumption of solvents, together with a considerable production of chemical waste.

An alternative to conventional HPLC methods is ultra-performance liquid chromatography (UPLC), based on the use of columns with sub- $2 \mu \mathrm{m}$ diameter particles, that could render faster and high-resolution separations. Recently, an UPLC-tandem mass spectrometry method for the simultaneous quantitation of several antifungals was described..$^{18}$ However, the coupling of UPLC to PDA detection allows fast analysis while keeping the advantages and robustness of UV detection modes, at a moderate cost. ${ }^{19}$ In the present work, we validated a novel and fast UPLC-PDA assay for TDM of VRC in human plasma and oral fluid samples, after a simple liquid-liquid extraction.

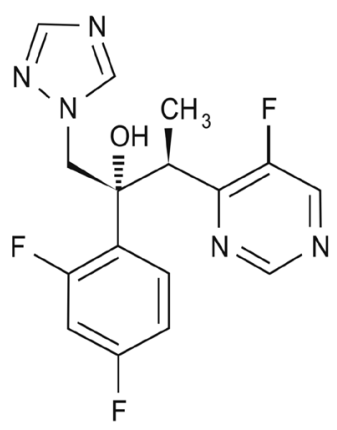

Figure 1. Chemical structure of voriconazole.

\section{Experimental}

\section{Chemicals}

VRC and its analogue UK 11579 (internal standard) were kindly donated by Pfizer (Croton, USA). Triethylammonium phosphate buffer $1 \mathrm{~mol} \mathrm{~L}^{-1} \mathrm{pH} 3.0$ was purchased from Fluka (Buchs, Switzerland). Tris(hydroxymethyl)aminomethane was purchased from Nuclear (Diadema, Brazil). Sodium hydroxide, methanol, acetonitrile and methyl-tert-butyl ether (MTBE) were obtained from Merck (Darmstadt, Germany). Ultrapure water was obtained through an Elga Purelab Ultra ${ }^{\circledast}$ apparatus from Elga Labwater (High Wycombe, UK).

\section{Preparation of solutions and standards}

Individual stock methanolic solutions of VRC and UK 11579 (IS) were prepared by powder dissolution in order to obtain a concentration of $1 \mathrm{mg} \mathrm{mL}^{-1}$. VRC working solutions were prepared combining aliquots of each stock solution and proper volumes of methanol to obtain solutions containing 1.0, 2.5, 5.0, 10.0, 25.0, 50.0 and $100.0 \mu \mathrm{g} \mathrm{mL}^{-1}$ of VRC. The working internal standard solution was prepared by dilution of stock with methanol to obtain a $20 \mu \mathrm{g} \mathrm{mL}^{-1}$ concentration. Mobile phase buffer was prepared daily diluting $500 \mu \mathrm{L}$ of triethylammonium phosphate buffer $1 \mathrm{~mol} \mathrm{~L}^{-1}$ to $100 \mathrm{~mL}$ with ultrapure water to obtain a $5 \mathrm{mmol} \mathrm{L}^{-1}$ concentration, followed by filtration with $0.2 \mu \mathrm{m}$ cellulose acetate membranes from Sartorius (Göettingen, Germany). Tris buffer $\mathrm{pH} 10.0$ was prepared dissolving $2.43 \mathrm{~g}$ of tris(hydroxymethyl)aminomethane in $100 \mathrm{~mL}$ of ultrapure water, and the $\mathrm{pH}$ was properly adjusted with $\mathrm{NaOH} 0.1 \mathrm{~mol} \mathrm{~L}^{-1}$.

\section{Equipment and chromatographic conditions}

The UPLC system consisted of an ACQUITY UPLC $^{\circledR}$ coupled to an ACQUITY UPLC ${ }^{\circledR}$ photodiode array detector, both from Waters (Milford, USA). The separation was performed on a Hypersil Gold ${ }^{\circledR} \mathrm{C} 18$ column $(2.1 \times 100 \mathrm{~mm}$, particle diameter $1.9 \mu \mathrm{m})$, from Thermo Scientific (San Jose, USA). The system was controlled and data was managed by Empower ${ }^{\circledR}$ software, also from Waters. Mobile phase was a mixture of triethylammonium phosphate buffer $5 \mathrm{mmol} \mathrm{L}^{-1}$ and acetonitrile (70:30, v/v), which was sonicated for $15 \mathrm{~min}$ before use. The flow rate was $0.55 \mathrm{~mL} \mathrm{~min}^{-1}$, and total run time was $4 \mathrm{~min}$. The column temperature was set at $55{ }^{\circ} \mathrm{C}$. Spectra were acquired for all peaks in the range of 205 to $380 \mathrm{~nm}$ and the quantitation wavelength was $256 \mathrm{~nm}$.

\section{Sample preparation}

To $2 \mathrm{~mL}$ disposable polypropylene tubes, $500 \mu \mathrm{L}$ of either calibration, quality control or patient's samples (plasma or oral fluid) were added, followed by $50 \mu \mathrm{L}$ of working internal standard solution, $100 \mu \mathrm{L}$ of Tris buffer $\mathrm{pH} 10.0$ and 1,000 $\mu \mathrm{L}$ of methyl-tert-butyl ether. The tubes were capped and vortex mixed for $30 \mathrm{~s}$ and then 
centrifuged at $10,000 \times g$ for $10 \mathrm{~min}$ at $4{ }^{\circ} \mathrm{C}$. An aliquot of $900 \mu \mathrm{L}$ of the organic layer was evaporated to dryness at $50{ }^{\circ} \mathrm{C}$, under a gentle stream of air. The dried extract was recovered with $150 \mu \mathrm{L}$ of mobile phase, vortex mixed for $30 \mathrm{~s}$ and centrifuged at $10,000 \times g$ for $10 \mathrm{~min}$, at $4{ }^{\circ} \mathrm{C}$. The supernatant was transferred to an autosampler vial and $10 \mu \mathrm{L}$ were injected into the UPLC system.

\section{Selectivity}

Blank plasma and oral fluid samples from 6 different sources were prepared as described above to check for peaks that might interfere with the detection of the analyte or the IS. In addition, the use of a photodiode array detector (PDA) permitted to check for the presence of spectral impurities in each chromatographic peak.

\section{Stability}

For estimation of stability of processed samples under the conditions of analysis, control samples at 0.2 and $8.0 \mu \mathrm{gLL}^{-1}(\mathrm{n}=5$ each) were extracted as described above. The extracts obtained at each concentration were pooled. Aliquots of these pooled extracts at each concentration were transferred to autosampler vials and injected under the conditions of a regular analytical run at time intervals of $1 \mathrm{~h}$, during $12 \mathrm{~h}$. Stability of VRC was tested by regression analysis plotting absolute peak areas corresponding to each compound at each concentration $v s$. injection time. Using the obtained linear regression, the concentration after $12 \mathrm{~h}$ was calculated. A decrease or increase of up to $10 \%$ in the measured peak areas was considered as acceptable. For evaluation of freeze-thaw stability, quality control samples at 3 levels $\left(0.2 ; 2.0\right.$ and $\left.8.0 \mu \mathrm{g} \mathrm{mL}^{-1}\right)$ were analyzed before (control samples, $\mathrm{n}=3$ ) and after 3 freeze-thaw cycles (stability samples, $\mathrm{n}=9$ ). For each freeze-thaw cycle, the samples were frozen at $-20{ }^{\circ} \mathrm{C}$ for $48 \mathrm{~h}$, thawed, and kept at ambient temperature for $3 \mathrm{~h}$ before extraction. The concentrations of the control and stability samples were calculated from daily calibration curves and the variance evaluated using ANOVA test. $P$ values of $\leq 0.05$ were considered statistically significant.

\section{Linearity}

Aliquots of blank plasma or oral fluid $(450 \mu \mathrm{L})$ were enriched with $50 \mu \mathrm{L}$ of the corresponding working solutions to obtain calibration samples containing $0.1,0.25,0.50$ $1.0,2.5,5.0$, or $10.0 \mu \mathrm{g} \mathrm{mL}{ }^{-1}$ of VRC. Replicates $(\mathrm{n}=6)$ at each concentration for both matrices were analyzed as described above. Calibration curves were constructed by calculating the ratios of the peak area of VRC to the peak area of the internal standard and relating these ratios with nominal concentrations of the calibration samples. Homoscedasticity of calibration data was evaluated with F-test at the confidence level of 95\%. Curves were fitted by least-squares linear regression using several weighting factors $\left(1 / \mathrm{x}, 1 / \mathrm{x}^{0.5}, 1 / \mathrm{x}^{2}, 1 / \mathrm{y}, 1 / \mathrm{y}^{0.5}, 1 / \mathrm{y}^{2}\right)$. The calibration models were evaluated by their correlation coefficients (r) and cumulative percentage relative error ( $\left.\sum \% \mathrm{RE}\right)$, according to Almeida et al. ${ }^{20}$ The correlation between the calibration curves obtained from plasma and oral fluid was established by linear regression and evaluated through the coefficient of correlation. Daily calibration curves using the same concentrations (single measurements per concentration) were prepared with each batch of validation and authentic samples.

\section{Accuracy and precision}

Aliquots of blank plasma and oral fluid $(450 \mu \mathrm{L})$ were enriched with $50 \mu \mathrm{L}$ of the corresponding working solutions to obtain quality control samples containing VRC at 0.20 (quality control low, QCL), 2.0 (quality control medium, QCM) and $8.0 \mu \mathrm{g} \mathrm{mL}^{-1}$ (quality control high, QCH). The quality control samples were analyzed as described above in triplicate on each of 5 days. Withinassay precision and between-day precision were calculated by one-way ANOVA with the grouping variable "day" and were expressed as CV\%. Accuracy was defined as the percentage of the nominal concentration represented by the concentration estimated with the calibration curve. The acceptance criterion for accuracy was mean values within $\pm 15 \%$ of the theoretical value and for precision was a maximum $\mathrm{CV}$ of $15 \% .{ }^{21}$ Additionally, the method was applied to 2 plasma samples from the antifungal interlaboratorial quality control program of Kwaliteitsbewaking Klinische Geneesmiddelanalyse en Toxicologie, The Hague, The Netherlands, which contained VRC at the nominal concentrations of 4.4 (proficiency test low, PTL) and $8.0 \mu \mathrm{g} \mathrm{mL}^{-1}$ (proficiency test high, PTH).

\section{Lower limit of quantitation}

The lowest point of the calibration curve was $0.1 \mu \mathrm{g} \mathrm{mL}^{-1}$. An independent quality control sample at this concentration was included in the accuracy and precision experiments (quality control at the lower limit of quantitation, QCLLOQ) and was tested in triplicate in three different days. The acceptance criteria established for the limit of quantification was accuracy within $100 \pm 20 \%$ of the nominal value and a maximum $\mathrm{CV}$ of $20 \% .^{21}$ 


\section{Extraction efficiency}

The extraction efficiency was determined by comparing the peak areas of the analytes obtained at the plasma QC samples of the accuracy and precision experiments to those obtained with methanolic solutions at levels corresponding to complete recovery, measured in triplicate at three different days, in the same analytical batch. Extraction efficiency was expressed as percentage of the concentration of the reference samples.

\section{Method application}

The developed method was applied to 15 paired samples of plasma and oral fluid obtained from 9 patients, collected from March 2010 to January 2011. All patients were adults, over 18 year of age. Trough blood samples, collected at day 2 and 5 after initiation of VRC therapy, were collected by venipuncture to EDTA containing tubes. After collection, the tubes were centrifuged within $10 \mathrm{~min}$ and plasma was separated. The oral fluid samples were collected at the same times by chewing on the cotton wool swabs of a commercial saliva collecting device (Salivette ${ }^{\circledR}$, Sarstedt, Germany) impregnated with citric acid. The chewing time was standardized in $2 \mathrm{~min}$. Plasma and oral fluid samples were kept at $-20{ }^{\circ} \mathrm{C}$ until analysis. Written informed consent was obtained from all patients. The study was approved by the Ethics Committee of the Irmandade da Santa Casa de Misericórdia de Porto Alegre (Porto Alegre, Brazil).

\section{Results and Discussion}

\section{Chromatography and sample preparation}

Most HPLC-UV methods for chromatographic determination of VRC have long run times or high consumption of mobile phases, reducing their applicability for routine analysis, along with high costs associated to the use of solvents and the disposal of chemical residues. In this study we described a fast LC-UV method for the measurement of VRC. This is the first description of the use of columns with sub- $2 \mu \mathrm{m}$ particle diameter to this drug. The combination of a narrow bore column with small diameter particles, allowed a rapid and efficient separation of the analytes, despite the higher linear velocity of mobile phase. As a consequence of these conditions, a high operating pressure of the system was observed, with typical run pressures over 7,000 psi, which are not supportable by conventional HPLC equipments, requiring special instrumentation. Retention times for VRC and IS were 3.05 and $3.65 \mathrm{~min}$, respectively (Figure 2), with
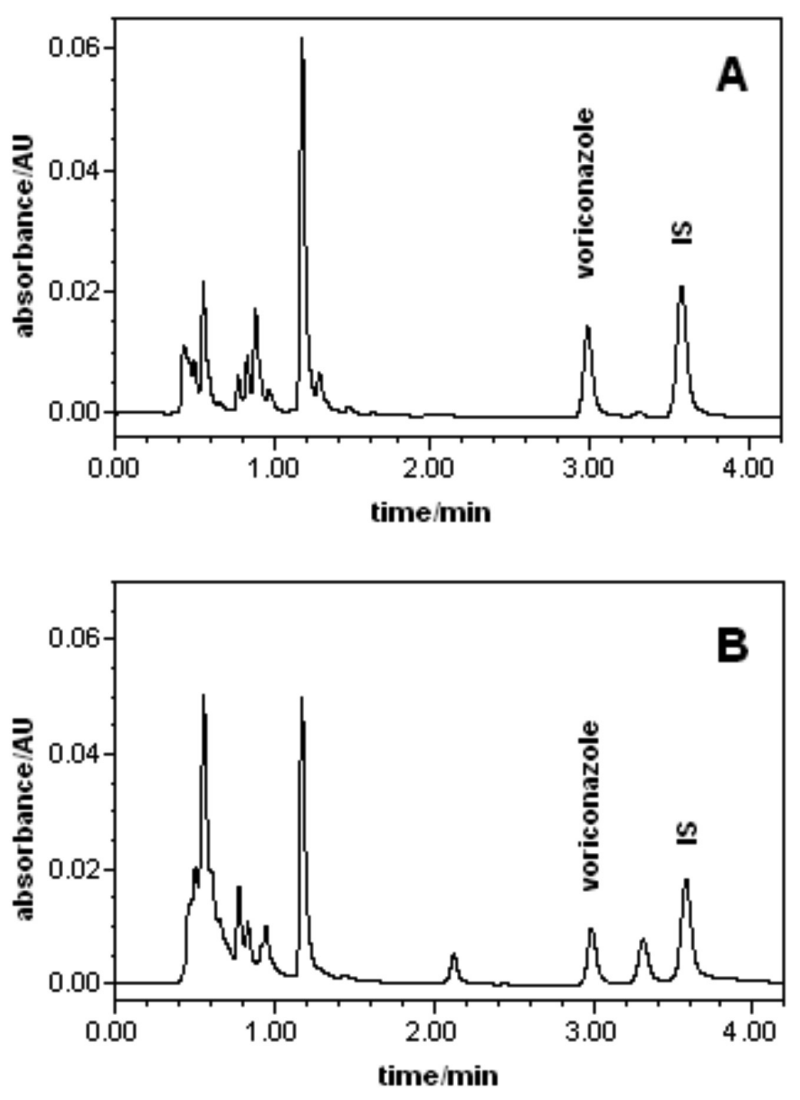

Figure 2. Chromatograms from samples of the same patient, obtained simultaneously 5 days after initiation of voriconazole therapy, monitored at $256 \mathrm{~nm}$; A: Plasma sample with concentration of $1.1 \mu \mathrm{g} \mathrm{mL} \mathrm{mL}^{-1}$. B: Oral fluid sample plasma with concentration of $0.58 \mu \mathrm{g} \mathrm{mL}^{-1}$.

a total run time of $4 \mathrm{~min}$. There is only one report of a LC-UV method for VRC determination with a similar run time, from Chhun et al., ${ }^{15}$ that employed a monolithic column with high mobile phase flow rate, in the order of $3.5 \mathrm{~mL} \mathrm{~min}^{-1}$, resulting in a total consumption of mobile phase of $14 \mathrm{~mL}$ for run. Other LC-UV published method had higher run times, in the order of 10-20 min, and higher mobile phase consumptions, from 8-15 mL. ${ }^{10,13-16}$ Total use of mobile phase in our assay was only $2.2 \mathrm{~mL}$ per analysis, considerably lower than other published LC-UV methods.

Interfering endogenous plasma peaks were not observed in the blank plasma and oral fluid samples (Figure 3). Additionally, all analyte's peaks were evaluated with respect to their spectral purity and compared with library reference spectra, using the Empower ${ }^{\circledR}$ software. No spectral impurity was observed in identified peaks or in any patient's tested sample.

In the present work, by means of simplicity and cost, we choose a liquid-liquid extraction procedure with MTBE to extract the drugs from plasma and oral fluid. The small volume of solvent taken for evaporation $(900 \mu \mathrm{L})$ allowed a fast concentration of the samples, in the order 

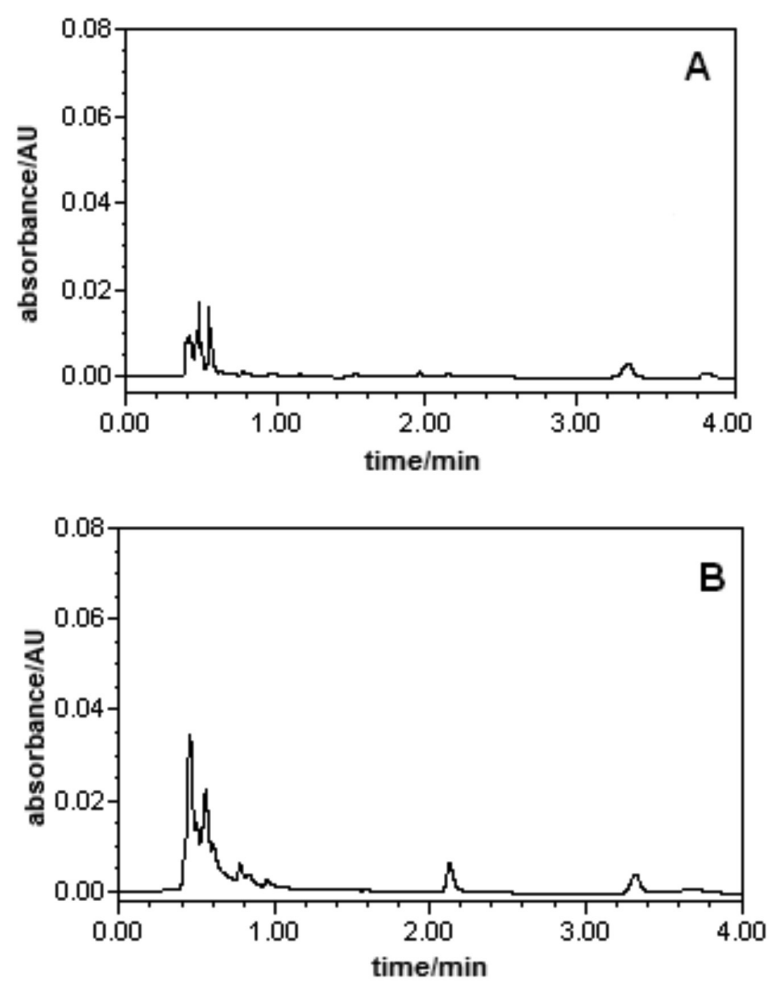

Figure 3. Chromatograms monitored at $256 \mathrm{~nm}$; A: Blank plasma sample. B: Blank oral fluid sample.

of $5 \mathrm{~min}$. Considering the possibility of clogging in the column, especially due to the small inter-particle spaces, an additional step of centrifugation was employed after recovery of the dried extract with mobile phase. However, the extraction procedure was rapid, simple and inexpensive, with consistent yields in the range of 80.6-81.8\% in plasma and $82.5-86.2 \%$ in oral fluid.

\section{Method validation}

There was no indication of instability of the analyte in any of the tested conditions. Regression analysis of absolute peak areas of the analytes plotted $v s$. injection time indicated no instability of processed samples during a time interval of $12 \mathrm{~h}$, with concentration changes based on linear regression on the range of -4.3 to $5.9 \%$ for plasma and -3.8 to 4.5 in oral fluid. The time frame of $12 \mathrm{~h}$ was determined considering the maximum run time needed for analysis of a large batch of samples with the developed method, even considering its high throughput. The ratios of means (stability $v s$. control samples) of the freeze-thaw samples also fulfilled the acceptance criteria $(p=0.05)$ for both matrices (Table 1).

Calibration samples were prepared at 6 concentrations spread from 0.1 to $10 \mu \mathrm{g} \mathrm{mL} \mathrm{m}^{-1}$ of VRC, covering concentrations that are to be expected for most authentic plasma and oral fluid samples. The slopes (b) and $y$-intercepts (a), including 95\% confidence intervals of both variables, as well as the coefficients of correlation and cumulative percentage relative error ( $\left.\sum \% \mathrm{RE}\right)$, as obtained in the linearity experiments, are listed in Table 2. Several weighted regression models were evaluated in order to account to the significant heteroscedasticity of the calibration data. The best weighting factor was chosen according to the $\sum \% \mathrm{RE}$, defined as the sum of absolute percentage relative error, which compares the regressed concentration computed from the regression equation obtained for each weighting factor, with the nominal standard concentration. The inverse of the concentration ( $1 / \mathrm{x})$ was selected as the best weighting factor, with maximum $\sum \%$ RE of $-5.3 \times 10^{-15}$ for plasma and $\sum \%$ RE of $9.77 \times 10^{-14}$ for oral fluid, contrasting to a maximum $\sum \% \mathrm{RE}$ of 84.31 for plasma and $\Sigma \% \mathrm{RE}$ of 27.55 for oral fluid when unweighted regression was applied. The coefficients of correlation were above 0.999 for all weighing factors. The back-calculated concentrations of all calibration samples fulfilled the criteria established by Shah et $a l .^{21}$

QC samples for accuracy and precision experiments were prepared at 3 concentrations (QCL, QCM, and $\mathrm{CQH})$ covering the calibration range. The results of the

Table 1. Freeze and thaw stability

\begin{tabular}{|c|c|c|c|c|c|}
\hline \multirow[t]{3}{*}{$\mathrm{VRC} /\left(\mu \mathrm{g} \mathrm{mL}^{-1}\right)$} & \multirow{3}{*}{$\begin{array}{c}\text { Benchtop stability } \\
\begin{array}{c}\text { Concentration change after } 12 \mathrm{~h} \\
\text { (based on regression) } / \%\end{array}\end{array}$} & \multicolumn{4}{|c|}{ Freeze and thaw stability } \\
\hline & & \multicolumn{4}{|c|}{ Control concentration after each cycle $(n=3)$} \\
\hline & & First & Second & Third & $P$ value (ANOVA) \\
\hline \multicolumn{6}{|l|}{ Plasma } \\
\hline 0.20 & -4.3 & 0.18 & 0.18 & 0.19 & 0.45 \\
\hline 2.00 & - & 2.02 & 2.11 & 2.05 & 0.46 \\
\hline 8.00 & 5.9 & 8.30 & 8.37 & 8.23 & 0.41 \\
\hline \multicolumn{6}{|l|}{ Oral fluid } \\
\hline 0.20 & -3.8 & 0.24 & 0.21 & 0.20 & 0.10 \\
\hline 2.00 & - & 1.98 & 1.98 & 1.97 & 0.51 \\
\hline 8.00 & 4.5 & 7.80 & 7.76 & 7.89 & 0.29 \\
\hline
\end{tabular}


Table 2. Summary of the evaluation of the calibration models

\begin{tabular}{|c|c|c|c|}
\hline Weighting factor & $\begin{array}{l}\text { Regression } \\
\text { parameters }\end{array}$ & Plasma & Oral fluid \\
\hline \multirow[t]{4}{*}{ unweighted } & $\mathrm{b}$ & 0.5390 & 0.5385 \\
\hline & a & -0.0363 & -0.0213 \\
\hline & $\mathrm{r}$ & 0.9999 & 0.9999 \\
\hline & $\sum \% \mathrm{RE}$ & 84.309 & 27.554 \\
\hline \multirow[t]{4}{*}{$1 / \mathrm{x}$} & $\mathrm{b}$ & 0.5281 & 0.5350 \\
\hline & a & -0.0063 & -0.0115 \\
\hline & $\mathrm{r}$ & 0.9999 & 0.9999 \\
\hline & $\sum \% \mathrm{RE}$ & $-5.3 \times 10^{-15}$ & $9.7 \times 10^{-14}$ \\
\hline \multirow[t]{4}{*}{$1 / \mathrm{x}^{0.5}$} & $\mathrm{~b}$ & 0.5334 & 0.5371 \\
\hline & a & -0.0149 & -0.0156 \\
\hline & $\mathrm{r}$ & 0.9999 & 0.9999 \\
\hline & $\sum \% \mathrm{RE}$ & 21.563 & 10.535 \\
\hline \multirow[t]{4}{*}{$1 / \mathrm{x}^{2}$} & $\mathrm{~b}$ & 0.5150 & 0.5201 \\
\hline & $\mathrm{a}$ & -0.0011 & -0.0057 \\
\hline & $\mathrm{r}$ & 0.9999 & 0.9999 \\
\hline & $\sum \% \mathrm{RE}$ & $-1.2 \times 10^{-13}$ & $7.11 \times 10^{-14}$ \\
\hline \multirow[t]{4}{*}{$1 / \mathrm{y}$} & $\mathrm{b}$ & 0.5277 & 0.5348 \\
\hline & $\mathrm{a}$ & -0.0062 & -0.0116 \\
\hline & $\mathrm{r}$ & 0.9999 & 0.9999 \\
\hline & $\sum \% \mathrm{RE}$ & 0.2644 & 0.3585 \\
\hline \multirow[t]{4}{*}{$1 / \mathrm{y}^{0.5}$} & $\mathrm{~b}$ & 0.5332 & 0.5371 \\
\hline & $\mathrm{a}$ & -0.0148 & -0.0156 \\
\hline & $\mathrm{r}$ & 0.9999 & 0.9999 \\
\hline & $\sum \% \mathrm{RE}$ & 21.447 & 10.563 \\
\hline \multirow[t]{4}{*}{$\overline{1 / y^{2}}$} & $\mathrm{~b}$ & 0.5142 & 0.5174 \\
\hline & $\mathrm{a}$ & -0.0010 & -0.0054 \\
\hline & $\mathrm{r}$ & 0.9999 & 0.9999 \\
\hline & $\sum \% \mathrm{RE}$ & 0.8495 & 2.828 \\
\hline $\begin{array}{l}\text { Test of homoscedasticity } \\
\mathrm{F}_{\text {tab }}(5.05 .00 .95)=5.05\end{array}$ & $\mathrm{~F}_{\text {exp }}$ & 211.36 & 2881.64 \\
\hline
\end{tabular}

accuracy and precision experiments are given in Table 3. All accuracy values fulfilled the acceptance criteria for this parameter, lying within the range $96.3-99.8 \%$ of the nominal concentrations for plasma and $99.3-103.4 \%$ for oral fluid samples. Within-assay precision was in the range of $2.8-4.5 \%$ for plasma and $2.5-4.9 \%$ for oral fluid, where between-assay precision was $1.4-4.9 \%$ for plasma and 1.3-3.8\% for oral fluid, also being accepted. An additional evaluation of the method accuracy was done by analyzing two proficiency test samples (PTL and PTH). The measured values were in close agreement with target values, being $4.34 \mu \mathrm{g} \mathrm{mL}^{-1}$ for PTL (target value $4.4 \mu \mathrm{g} \mathrm{mL}^{-1}$, accuracy 98.6\%) and $8.07 \mu \mathrm{g} \mathrm{mL}^{-1}$ for PTH (target value $8.0 \mu \mathrm{g} \mathrm{mL} \mathrm{L}^{-1}$, accuracy $100.9 \%)$.

Another QC sample containing VRC at a concentration equal to those of the lowest point of the calibration curve (QCLLOQ) was prepared to determine whether the criteria for analytical recovery and precision were fulfilled even at this concentration, which corresponded to the practical LOQ. The plasma QCLLOQ presented mean accuracy of $102.7 \%$, within-assay precision of $6.8 \%$, and betweenassay of $4.5 \%$, whereas the oral fluid QCLLOQ presented mean accuracy of $108.2 \%$, within-assay precision of $7.2 \%$, and between-assay of $5.9 \%$, both fulfilling the acceptance criteria for the lower limit of quantification.

\section{Method application}

The developed method was applied to 15 paired plasma and oral fluid samples, collected at trough conditions (Table 4). A wide range of concentrations were observed, with a 10 fold difference between the lower and the

Table 3. Precision, accuracy and extraction yield*

\begin{tabular}{|c|c|c|c|c|c|}
\hline \multirow{2}{*}{$\mathrm{QC}$ sample / $\left(\mu \mathrm{g} \mathrm{mL}^{-1}\right)$} & \multirow{2}{*}{$\begin{array}{l}\text { Nominal concentration / } \\
\qquad(\mu \mathrm{g} \mathrm{mL}-1)\end{array}$} & \multicolumn{2}{|c|}{ Precision / (CV\%) } & \multirow{2}{*}{ Accuracy / \% } & \multirow{2}{*}{ Extraction yield / \% } \\
\hline & & Within-assay & Between-assay & & \\
\hline \multicolumn{6}{|l|}{ Plasma } \\
\hline QCLLOQ & 0.1 & 6.8 & 4.5 & 102.1 & - \\
\hline QCL & 0.2 & 2.8 & 1.4 & 96.3 & 80.6 \\
\hline QCM & 2.0 & 4.5 & 4.9 & 97.3 & 81.8 \\
\hline $\mathrm{QCH}$ & 8.0 & 3.2 & 4.3 & 99.8 & 81.7 \\
\hline PTL & 4.4 & - & - & 98.6 & - \\
\hline PTH & 8.0 & - & - & 100.9 & - \\
\hline \multicolumn{6}{|l|}{ Oral Fluid } \\
\hline QCLLOQ & 0.1 & 7.2 & 5.9 & 108.2 & - \\
\hline QCL & 0.2 & 3.3 & 2.1 & 101.0 & 84.5 \\
\hline QCM & 2.0 & 4.9 & 3.8 & 99.3 & 86.2 \\
\hline $\mathrm{QCH}$ & 8.0 & 2.5 & 1.3 & 103.4 & 82.5 \\
\hline
\end{tabular}

*n = 15 for QCL, QCM and QCH; $\mathrm{n}=9$ for QCLLOQ; $\mathrm{n}=1$ for PT samples. 
Table 4. Plasma and oral fluid trough levels and OF/P ratios

\begin{tabular}{lcccc}
\hline Patient & $\begin{array}{c}\text { Days after } \\
\text { initiation of } \\
\text { VRC }\end{array}$ & $\begin{array}{c}\text { Plasma } \\
\text { trough level / } \\
\left(\mu \mathrm{gL}^{-1}\right)\end{array}$ & $\begin{array}{c}\text { Oral fluid } \\
\text { trough level / } \\
\left(\mu \mathrm{gL}^{-1}\right)\end{array}$ & $\begin{array}{c}\text { OF/P } \\
(\%)\end{array}$ \\
\hline 1 & 5 & 3.85 & 2.02 & 52.4 \\
2 & 2 & 1.78 & 0.94 & 52.6 \\
2 & 5 & 1.11 & 0.58 & 52.0 \\
3 & 2 & 2.83 & 1.68 & 59.3 \\
3 & 5 & 1.97 & 1.26 & 63.8 \\
4 & 2 & 8.24 & 4.78 & 58.0 \\
4 & 5 & 8.11 & 4.39 & 54.2 \\
5 & 5 & 0.84 & 0.54 & 64.3 \\
6 & 2 & 1.92 & 1.02 & 53.5 \\
6 & 5 & 2.44 & 1.28 & 52.4 \\
7 & 2 & 0.61 & 0.38 & 61.5 \\
7 & 5 & 1.50 & 1.02 & 67.9 \\
8 & 2 & 8.49 & 4.52 & 53.3 \\
9 & 2 & 4.71 & 2.60 & 55.3 \\
9 & 5 & 4.14 & 2.58 & 62.3 \\
\hline Range & & $0.84-8.49$ & $0.54-4.52$ & $52.0-67.9$ \\
Mean $( \pm \mathrm{sd})$ & & $3.50( \pm 2.7)$ & $1.97( \pm 1.5)$ & $57.5( \pm 5.3)$ \\
\hline
\end{tabular}

OF: oral fluid; P: plasma; VRC: voriconazole.

higher plasma measured concentrations. In oral fluid, the concentration span was a little smaller, of 8.4 fold. In the 15 measured plasma concentrations, 3 were above the upper proposed threshold of $6 \mu \mathrm{g} \mathrm{mL}^{-1}$ and 2 were below the lower expected concentration of $1 \mu \mathrm{g} \mathrm{mL}^{-1}$, with one third of all measurement outside the expected therapeutic range. The use of oral fluid for VRC TDM was previously described by Michael et al. ${ }^{9}$ and is supported by the physico-chemical characteristics of this drug, especially its pKa of $1.76^{22}$ (with ionization being unaffected by usual mouth's $\mathrm{pH}$ ) and its protein binding of 58\% ${ }^{23}$ Interestingly, the percentage of oral fluid related to plasma concentration was relatively stable, ranging from 52.0-67.9\%, with mean of 57.5\%. However, these values were considerably different from those found by Michael et al., ${ }^{9}$ which were in the range of $14-56 \%$ with an overall mean of $40 \%$ in adult patients. The authors of the study did not mentioned the time expended by patients chewing the Salivette ${ }^{\circledR}$ cotton swab, and considering that we standardized this time in our procedure, this can be a possible source of variation. Considering that our sample size is limited, further studies are necessary to establish a clinically valid relation between VRC concentrations in plasma and oral fluid. However, oral fluid seems to be a useful alternative matrix for TDM of VRC.

\section{Conclusions}

A fast, simple and fully validated method was developed for the measurement of VRC in human plasma and oral fluid samples, using ultra-performance liquid chromatography, with the smallest consumption of mobile phase published so far. The method was applied to 15 paired plasma and oral fluid samples, showing a consistent ratio of concentrations in both matrices, with oral fluid presenting a mean of $57.5 \%$ of the plasma levels.

\section{Acknowledgments}

We thank Pfizer for the donation of reference samples of VRC and UK 11579, as well as Universidade Feevale for the financial support. Dr. Pasqualotto is thankful to CNPq (Conselho Nacional de Desenvolvimento Científico e Tecnológico), Brazilian Government Agency.

\section{References}

1. Walsh, T. J.; Anaissie, E. J.; Denning, D. W.; Herbrecht, R.; Kontoyianniset, D. P.; Marr, K. A.; Morrison, V. A.; Segal, B. H.; Steinbach, W. J.; Stevens, D. A.; van Burik, J.; Wingard, J. R.; Patterson, T. F.; Clin. Infect. Dis. 2008, 46, 327.

2. Herbrecht, R.; Denning, D. W.; Patterson, T. F.; Bennett, J. E.; Greene, R. E.; Oestmann, J. W.; Kern, W. V.; Marr, K. A.; Ribaud, P.; Lortholary, O.; Sylvester, R.; Rubin, R. H.; Wingard, J. R.; Stark, P.; Durand, C.; Caillot, D.; Thiel, E.; Chandrasekar, P. H.; Hodges, M. R.; Schlamm, H. T.; Troke, P. F.; de Pauw, B.; N. Engl. J. Med. 2002, 347, 408.

3. http://www.accessdata.fda.gov/drugsatfda_docs/ label/2010/021266s032lbl.pdf accessed in September 2011.

4. Trifilio, S.; Ortiz, R.; Pennick, G.; Verma, A.; Pi, J.; Stosor, V.; Zembower, T.; Mehta, J.; Bone Marrow Transplant. 2005, 35, 509.

5. Johnson L. B.; Kauffman C. A.; Clin. Infect. Dis. 2003, 36, 630.

6. Denning, D. W.; Ribaud, P.; Milpied, N.; Caillot, D.; Herbrecht, R.; Thiel, E.; Haas, A.; Ruhnke, M.; Lode, H.; Clin. Infect. Dis. 2002, 34, 563.

7. Pascual, A.; Calandra, T.; Bolay, S; Buclin, T.; Bille, J.; Marchetti, O.; Clin. Infec. Dis. 2008, 46, 201.

8. Pasqualotto, A. C.; Xavier, M. O.; Andreolla, H. F.; Linden, R.; Expert Opin. Drug Saf. 2010, 9, 125.

9. Michael, C.; Bierbach, U.; Frenzel, K.; Lange, T.; Basara, N.; Niederwieser, D.; Mauz-Körholz, C.; Preiss, R.; Ther. Drug Monit. 2010, 32, 194.

10. Zhou, L.; Glickman, R. D.; Chen, N.; Sponsel, W. E.; Graybill, J. R.; Lam, K. W.; J. Chromatogr., B: Anal. Technol. Biomed. Life Sci. 2002, 776, 213.

11. Keevil, B. G.; Newman, S.; Lockhart, S.; Howard, S. J.; Moore, C. B.; Denning, D. W.; Ther. Drug Monit. 2004, 26, 650.

12. Vogeser, M.; Schiel, X.; Spohrer, U.; Clin. Chem. Lab. Med. 2005, 43, 730 .

13. Gage, R.; Stopher, D. A.; J. Pharm. Biomed. Anal. 1998, 17, 1449. 
14. Pennick, G. J.; Clark, M.; Sutton, D. A.; Rinaldi, M. G.; Antimicrob. Agents Chemother. 2003, 47, 2348.

15. Chhun, S.; Rey, E.; Tran, A.; Lortholary, O.; Pons, G.; Jullien, V.; J. Chromatogr., B: Anal. Technol. Biomed. Life Sci. 2007, $852,223$.

16. Langman, L. J.; Boakye-Agyeman, F.; Clin. Biochem. 2007, 40, 1378.

17. Pragst, F.; Herzler, M.; Erxleben, B. T.; Clin. Chem. Lab. Med. 2004, 42, 1325.

18. Decosterd, L. A.; Rochat, B.; Pesse, B.; Mercier, T.; Tissot, F.; Widmer, N.; Bille, J.; Calandra, T.; Zanolari, B.; Marchetti, O.; Antimicrob. Agents Chemother. 2010, 54, 5303.

19. Antunes, M. V.; Poeta, J.; Ribeiro, J. P.; Sprinz, E.; Linden, R.; J. Braz. Chem. Soc. 2011, 22, 134.
20. Almeida, A. M.; Castel-Branco, M. M.; Falcão, A. C.; J. Chromatogr., B: Anal. Technol. Biomed. Life Sci. 2002, $774,215$.

21. Shah, V. P.; Midha, K. K.; Findlay, J. W. A.; Hill, H. M.; Hulse, J. D.; McGilveray, I. J.; McKay, G.; Miller, K. J.; Patnaik, R. N.; Powell, M. L.; Tonelli, A.; Viswanathan, C. T.; Yacobi, A.; Pharm. Res. 2000, 17, 1551.

22. Adams, A. I.; Morimoto, L. N.; Meneghini, L. Z.; Bergold, A. M.; Braz. J. Infect. Dis. 2008, 12, 400.

23. Drobitch, R. K.; Svensson, C. K.; Clin. Pharmacokinet. 1992, 23,365 .

Submitted: March 25, 2011

Published online: November 8, 2011 